Лекції

\title{
Mechanisms of regeneration of the endothelium at diabetes mellitus
}

\section{H.S. Kuznetsova,}

K.S. Kuznetsova,

T.M. Byts,

\section{L.M. Bobryk,}

O.M. Kuznetsova,

\section{A.I. Gozhenko}

State Enterprise Ukrainian Research Institute of Transport Medicine, Ministry of Health of Ukraine, Odessa

\begin{abstract}
Vascular endothelium is the main organ, suffering from diabetes mellitus (DM) and cardiovascular diseases (CVD). In this review, the role of endothelial progenitor cells (EPCS) in the regeneration of the endothelium and in the formation of new blood vessels is considered. Mechanisms of migration and mobilization of EPCs from the bone marrow to the damage zone are described. The analyzed data show that CVD and DM cause the decrease in the number and the disturbance of the function of EPCs. The data on the heterogeneity of the population of EPCs are presented in article. The various combinations of surface markers for identification of these cells are assessed. At the same time, protocols for the identification of EPCs have not been developed, which confirms the relevance of the search for the phenotype of EPCs, which would be adopted as the standard.
\end{abstract}

Keywords: endothelial progenitor cells, angiogenesis, endothelial regeneration, endothelial dysfunction, diabetes mellitus.

This work is a fragment of research and development work 'Investigation of endothelial dysfunction in diabetes mellitus and the possibility and effectiveness of the use of a new method for treating patients with diabetes mellitus'. № of state registration $0118 \mathrm{U} 001852$.

Diabetes mellitus (DM) is a serious problem of the XXI century, and despite a wide range of modern medicines, type 1 (T1DM) and type 2 (T2DM) diabetes mellitus is inevitably progressing. The American Heart Association has classified T2DM as a cardiovascular disease (CVD) due to the high risk of

* Адреса для листування (Correspondence): ДП «Український науково-дослідний інститут медицини транспорту МОЗ України» вул. Канатна, 92, м. Одеса, 65039, Україна. E-mail: zdovado@ukr.net

(с Г.С. Кузнечова, К.С. Кузнечова, Т.М. Биць, Л.М. Бобрик, О.М. Кузнечова, А.І. Гоженко vascular complications. The basis of micro- and macroangiopathies in DM is endothelial dysfunction (ED), which is manifested by an imbalance between the production of vasodilators and vasoconstrictors, thrombogenic and atrombogenic factors. Moreover, ED represents imbalance between the degree of damage and the ability to restore [1-3].

Previously it was thought that vasculogenesis occurs only during embryonic development. Currently, vascular repair and postnatal angiogenesis are associated with endothelial progenitor cells (EPCs), which are a unique population of cells that participate in the formation of blood vessels due to angiogenesis and vasculogenesis [4].

EPCs were isolated in 1997 by Asahara et al. [5] from human peripheral blood based on expression 
on the hematopoietic stem cells' surface of the myeloid marker CD34 (cluster of differentiation 34) and marker of kinase insert domain receptor (KDR). These cells have been identified as immature bone marrow (BM) cells that have the ability to differentiate into mature endotheliocytes, therefore they are called «endothelial progenitor cells». The opening of EPCs has initiated a new era in studies of angiogenesis [5].

It is worth to note, that BM is the main, but not the only organ, that produces progenitor cells, possessing the ability to differentiate into mature endothelial cells (ECs). According to some reports, up to $70 \%$ of EPCs circulating in the blood are not cells of BM-origin. In particular, both circulating and localized in peripheral tissues, progenitor cells of other populations and monocytic-macrophage line cells can differentiate into endotheliocytes and stimulate angiogenesis [6].

In response to angiogenic growth factors, EPCs migrate from the BM niche into the blood, circulate and transform in the tissues into local adhesive EPCs. The participation of EPCs in neovascularization is not only due to their ability to differentiate into ECs and the replacement of dysfunctional ECs, but also due to the ability to secrete various regulatory growth factors and cytokines that stimulate vasculo- and angiogenesis. It was shown that EPCs account for up to $26 \%$ of all ECs in neovascularization [7].

When the peripheral tissues are under conditions of inflammation, damage or ischemia, EPCs exit from the BM in the bloodstream and migrate to the zone of injury. The entry of EPCs into the damaged area is a complex coordinated multi-step process that includes several consistent stages: mobilization, chemotaxis, adhesion, migration through the vessel wall and cell differentiation involving growth factors, chemokines and adhesion molecules. The process of attracting and migrating EPCs in the body is controlled by cells that are actually located in the area of the damage $[1,8]$.

The large group of substances that stimulate or inhibit angiogenesis is known (Tabl.). [9].
Table. Angiogenic stimulators and inhibitors

\begin{tabular}{|c|c|}
\hline PROANGIOGENIC FACTORS & ANTI-ANGIOGENIC FACTORS \\
\hline $\begin{array}{l}\text { Acidic \& basic fibroblast growth factors } \\
\text { (aFGF, bFGF) }\end{array}$ & 2-Methoxyestradiol \\
\hline Adenosine & Angiopoietin 2 \\
\hline Angiogenin & Angiostatin \\
\hline Angiopoetin 1 & Angiotensin II (AT-II) \\
\hline Angiotensin I (AT-I) & Antithrombin III (AT III) \\
\hline Angiotropin & Arrestin \\
\hline Brain-derived neurotrophic factor (BDNF) & Canstatin \\
\hline Cathepsin & Cartilage-derived inhibitor (CDI) \\
\hline Cyclooxygenase 2 (COX-2) & Caveolin 1,2 \\
\hline Developmental endothelial locus 1 (Del-1) & Chondromodulin \\
\hline Ephrin & Cortisol \\
\hline Epidermal growth factor (EGF) & Endorepellin \\
\hline Estrogen & Endostatin \\
\hline Follistatin & Fibronectin \\
\hline Glial cell derived neurotrophic factor (GDNF) & Fibronectin-binding integrins \\
\hline Granulocyte-colony stimulating factor (G-CSF) & Heparin hexasaccharide \\
\hline $\begin{array}{l}\text { Granulocyte-macrophage colonystimulating } \\
\text { factor (GM-CSF) }\end{array}$ & $\begin{array}{l}\text { Human chorionic gonadothropin } \\
\text { (hCG) }\end{array}$ \\
\hline Growth-regulated oncogene $\beta$ (GRO- $\beta$ ) & Interferon inducible protein (IP-10) \\
\hline Heparin-binding growth factor 8 (HBGF-8) & Interferon $\alpha, \beta, \mathrm{g}$ \\
\hline Hepatocyte growth factor (HGF) & $\begin{array}{l}\text { Interleukins (IL-4, IL-10, IL-12, IL-18, } \\
\text { IL-18) }\end{array}$ \\
\hline Histamine & Kallilrein-3 \\
\hline Hypoxia-inducible factor 1- $\alpha(H I F-1 \alpha)$ & Laminin \\
\hline Insulin-like growth factor 1 (IGF-1) & Maspin \\
\hline Interleukins (IL-1, IL-2, IL-6, IL-8, IL-18) & $\begin{array}{l}\text { Pigment epithelial derived factor } \\
\text { (PEDF) }\end{array}$ \\
\hline Leptin & Placental ribonuclease inhibitor (PRI) \\
\hline Leukotriene $\mathrm{C}_{4}$ & $\begin{array}{l}\text { Plasminogen activator inhibitor 1,2 } \\
\text { (PAI-1, PAl-2) }\end{array}$ \\
\hline Matrix metalloproteinases (MMPs) & Prolactin \\
\hline Monocyte chemoattractant protein-1 (MCP-1) & Proliferin-related protiei (PRP) \\
\hline Nerve growth factor (NGF) & Prothrombin kringle-2 \\
\hline Nicotinamide & Restin \\
\hline Nitric oxide synthase (NOS) & Retinoids \\
\hline Placental growth factor (PLGF) & $\begin{array}{l}\text { Soluble receptors for proangiogenic } \\
\text { factors }\end{array}$ \\
\hline Platelet factor IV & Transforming growth factor $\alpha, \beta$ \\
\hline Platelet-derived growth factor (PDGF) & Thrombospondin 1,2 \\
\hline Progranulin & $\begin{array}{l}\text { Tissue inhibitors of matrix } \\
\text { metalloproteinases (TIMPs) }\end{array}$ \\
\hline Proliferin & $\begin{array}{l}\text { Tumor necrosis factor } \alpha(T N F-\alpha) \text {, } \\
\text { high doses }\end{array}$ \\
\hline Prostaglandins $\mathrm{E}_{1}, \mathrm{E}_{2}$ & Troponin I \\
\hline Semaphorins & Tumstatin \\
\hline Stromal-cell-derived factor 1 (SDF-1) & Vasculostatin \\
\hline $\begin{array}{l}\text { Tissue and urokinase plasminogen activator } \\
\text { (tPA, UPA) }\end{array}$ & Vasostatin \\
\hline Transforming growth factor $\alpha, \beta$ (TGF- $\alpha, \beta)$ & Vasohibin 1 \\
\hline \multicolumn{2}{|l|}{ Tumor necrosis factor $\alpha$ (TNF- $\alpha)$, low doses } \\
\hline Vascular endothelial growth factors (VEGFs) & \\
\hline
\end{tabular}


Лекції

One of the most important inductors of angiogenesis is the group of vascular endothelial growth factors (VEGFs), angiogenic cytokines released under the influence of hypoxia by activated platelets and leukocytes. The angiogenic signal of VEGFs, mediated by tyrosine kinase receptors (VEGFR1 and VEGFR2), promotes proliferation, differentiation and EPCs chemotaxis in the area of injury or ischemia. VEGFs also induce the expression of stromal-cell-derived factor-1 (SDF-1). Additionally, VEGFs do not induce the proliferation of other vascular cells, such as pericytes, vascular smooth muscle cells (VSMCs) and fibroblasts, although VEGFs enhance the migration of VSMCs. Among VSMCs, the isoform VEGF165 is the most efficient regulator of angiogenesis in physiological and pathological states [10].

SDF-1 is produced by BM stromal cells and acts as a powerful chemoattractant for EPCs. SDF-1, binding to the CXCR-4 receptor on EPCs, stimulates targeted migration of cells to the ischemic zone [11]. Under physiological conditions, a low level of SDF-1 is determined in the blood, BM and other tissues, where SDF-1 is produced. This level creates a gradient that holds EPCs [11, 12]. In pathological conditions, this gradient in the $\mathrm{BM}$ is reversed by hypoxia-inducible factor $1-\alpha$ (HIF-1 $\alpha$ ), which stimulates SDF-1 and VEGFs in damaged tissues [13].

Nitric oxide (NO), estrogens, high-density lipoproteins and erythropoietin via the PI3K/Akt signaling pathway (phosphatidylinositide3-kinase) by activation of the endothelial NO-synthase (eNOS) also contribute to the mobilization of EPCs [13, 14].

Activated M2-type macrophages, through the production of granulocyte-colony stimulating factor ( $\mathrm{G}-\mathrm{CSF}$ ), also participate in the mobilization of EPCs from the BM in the bloodstream [15]. G-CSF induced mobilization of EPCs is associated with increased level of neutrophils in the blood circulation, which can lead to the release of VEGFs [16]. G-CSF stimulates the mobilization of hematopoietic progenitor cells (HPCs) through the release of elastase and cathepsin $G$ by neutrophils. These proteases disconnect EPCs, causing proteolytic cleavage of the vascular cell adhesion molecule 1 (VCAM-1 or CD106), which is expressed on the mesenchymal stem cells [17].

The synthesis of NO and the local activity of matrix metalloproteinases (MMPs), in particular matrix metalloproteinase-9 (MMP-9), influence on the attraction of EPCs from BM. MMP-9, which is regulated by SDF-1 and VEGFs, promotes the release of EPCs from adhesive interaction with stromal cells. This leads to the release of EPCs into the peripheral blood, causing the release of a soluble Kit ligand, which in turn, binds to tyrosine kinase (c-Kit or CD117) receptors, which are expressed on the surface of EPCs [9, 18].

After exiting the BM, EPCs migrate to the zone of injury and act in one of three directions: integration (restoration of the damaged site), the formation of new vessels or paracrine (the allocation of angiogenic factors). Binding of EPCs with the damaged endothelium and transmigration of cells through the endothelial monolayer is realized due to molecules of cell adhesion and selectins. $\mathrm{P} / \mathrm{E}$-selectin, intercellular adhesion molecule-1 (ICAM-1 or CD54), the platelet endothelial cell adhesion molecule (PECAM-1 or CD31), and the integrins $\alpha 4, \beta 1, \beta 2$, $\beta 3$ and $\beta 5$ are the most studied adhesion factors [19]. Moreover, EPCs are able to adhere not only to the endothelium, but also to platelets through interaction with P-selectin and GPIIb integrin [20-22].

The surfaces of endothelial cells in undamaged and noninflamed vessels are nonadhesive to circulating cells, including platelets. When vascular damage is severe, platelets are activated by exposed extracellular matrix proteins, and adhere to the bared vascular wall. Activation of platelets leads to the microthrombi formation and to the expression of SDF-1, which directs EPCs to the damaged endothelium.

After the processes of mobilization, migration, adhesion and invasion, EPCs begin to differentiate into mature ECs. Undifferentiated EPCs and mature ECs exert mutual influence on the functional state of each other, stimulating proliferation and migration through paracrine mechanisms. The paracrine effects of pro-angiogenic biologically active factors that are secreted by undifferentiated and mature ECs are comparable to the stimulating effect of angiogenic cytokines [8].

Reduction of the quantitative content of EPCs, a change in their functional capacity and mobilization potential have been revealed at many diseases, in which ED is considered as one of the most important pathogenetic mechanisms.

The participation of EPCs in angiogenesis has been confirmed by numerous studies at various diseases such as myocardial ischemia [23, 24], limb ischemia [25], DM [1, 26], ischemic stroke [27, 28], 
atherosclerosis [29], wounds [30] and others. At the same time, a decrease in proliferation, migration of EPCs to the lesion zone and changes in secretory activity are considered as a possible mechanism for the development of coronary heart disease and chronic heart failure. All these studies emphasize the diagnostic value of EPCs as a marker of CVD and DM [31].

In a cohort of patients with DM, a direct association between the amount of circulating EPCs and the intensity of oxidative stress was found [26]. At DM, a decrease in the concentration of EPCs is determined, which have a reduced ability to adhesion, proliferation and the formation of tubular-like structures [32]. Hyperglycemia and elevated levels of glycosylated hemoglobin are inversely correlated with the level of EPCs. The degree of inhibition of EPCs is associated with the severity of diabetic angiopathy [32].

An inevitable feature of T2DM is insulin resistance (IR). IR via the suppression of the PI3K/ eNOS pathway has a significant effect on the development of ED and the progression of atherosclerosis. There is a decrease in the bioavailability of NO and the mobilization of EPCs from BM as a result of the inactivation of the PI3K/eNOS pathway, which is also associated with reduced MMP-9 activity.

In the conditions of hyperglycemia, the toxic effect of glucose suppresses proliferation and enhances the apoptosis of EPCs by stimulating expression of different genes such as $\mathrm{p} 21^{\text {Waf1 }}$ and p16 $6^{\text {Ink4a }}$ [34].

Stimulation of $\mathrm{p} 16^{\text {Ink-4a }}$ and $\mathrm{p} 21^{\text {Waf-1 }}$ pathways leads to blocking of the cell division cycle. P38 mitogen-activated protein kinase (MAPK) is also related to hyperglycemia-induced suppression of EPCs [35].

Akt is known to be involved in signaling pathways that mediate the metabolic effects of insulin. Akt activity in the tissues of patients with DM increases and the constitutive activation of Akt in ECs promotes senescence-like arrest of cell growth via a p53/p21-dependent pathway, impaires angiogenesis and increases inflammation. It has shown that insulin also increases p53 activity and expression of p21 and that it promotes cellular senescence in an Akt-dependent manner [34].

The number of EPCs correlates with factors of cardiovascular risk, such as age, male gender, arterial hypertension, dyslipidemia, smoking, obesity, hyperuricemia, hypodynamia and depends on the total number of risk factors [37, 38]. An inverse correlation between the amount of EPCs and the functional state of the endothelium was also found. In addition, in individuals with high cardiovascular risk, the senescence of EPCs was faster than in those without risk factors [37, 38].

\section{Methods of identification of EPCs}

The number of circulating EPCs is small and amounts to $1-5 \%$ of the total population of $\mathrm{BM}$ cells and less than 0,0001-0,01\% of peripheral mononuclear cells circulating in the blood. There are 2 approaches to isolate them from peripheral blood, which are currently used: culture and colony formation analysis and selection of subpopulations based on surface markers. In clinical practice, the gold standard for the determination of EPCs is the flow cytometry method [39].

Identification of EPCs is a difficult task due to lack of standard protocol for the identification of EPCs, because the proposed combinations of markers are not completely specific for EPCs [39]. As a result, there are wide ranges of interlaboratory variations in the quantitative evaluation of EPCs [40].

EPCs express surface markers that are specific both for immature HPCs and mature cells of the endothelium. Markers of hematopoietic stem cells (CD34, CD133) and endothelial cell lines, such as endothelial growth factor receptor-2 (VEGFR-2), also known as KDR or CD309, are most often used to identify these cells. EPCs also express other endothelial markers, such as eNOS, tyrosine-protein kinase receptor (Tie-2), (c-kit or CD117) and E-selectin (CD62E) [40].

Other antigens, such as von Willebrand factor, PECAM-1 and vascular endothelial cadherin (VE-cadherin or CD144) are used to determine EPCs. It should be noted that these antigens are actually markers of mature ECs [42].

Circulating EPCs are not the result of differentiation of a one line of multipotent cells of bone marrow-derived cells (BM-EPCs), including those localized in peripheral tissues. They also include circulating progenitor cells of other populations, as well as cells of the monocyte-macrophage line, which are capable to differentiate into endotheliocytes. This is confirmed by the fact that $\mathrm{CD} 14^{+}$-myeloid subpopulations express both hematopoietic and endothelial markers and are able to differentiate in EPCs [43].

In dependence on the origin, EPCs express different surface markers. For example, CD31, CD144, CD146 and KDR are positive in EPCs, derived 
Лекції

from umbilical cord blood, and are negative or weak in BM-EPCs. At the same time, BM-EPCs and the EPCs, obtained from umbilical cord blood, express the CD105, CD73 and CD34 markers [44].

CD34 is the main transmembrane protein, widely represented on the membranes of circulating EPCs of the hemopoietic and mesenchymal lineage cells. CD34 ${ }^{+}$-progenitor cells are thought to differentiate in the direction of the two main lines: peripheral blood cells and ECs [45]. CD133, also known as prominin or AC133, is a transmembrane protein and is expressed on the surface of HPCs and usually does not occur in mature endotheliocytes and monocytes [46].

Currently, the combined expression of $\mathrm{CD}^{+} 4^{+} \mathrm{KDR}^{+}, \quad \mathrm{CD}^{+} 4^{+} \mathrm{CD} 133^{+}, \quad \mathrm{CD} 133^{+} \mathrm{KDR}^{+}$, $\mathrm{CD}_{14}{ }^{+} \mathrm{CD} 34^{\text {low }}, \mathrm{CD} 34^{+} \mathrm{CD} 45^{-}, \mathrm{CD} 14^{+} / \mathrm{Tie}-2 /$ $\mathrm{KDR}^{+}$, is widely used to identify EPCs [47].

It is believed that the $\mathrm{CD} 133^{+} \mathrm{KDR}^{+}$phenotype is associated with immature circulating EPCs, whereas the $\mathrm{CD} 34^{+} \mathrm{KDR}^{+}$complex can also be identified in immature endotheliocytes. Some authors suggest that the determination of CD133 antigen increases the specificity of EPCs [48]. Nevertheless, the number of $\mathrm{CD} 4^{+} \mathrm{KDR}^{+} \mathrm{CD} 133^{+}$-cells in the peripheral blood is much lower. Therefore, the quantitative determination of this phenotype becomes less reliable [49].

The phenotype of EPCs described as $\mathrm{CD} 4^{+} \mathrm{KDR}^{+}$is the most common, has the highest sensitivity and specificity and it is characterized by low expression of the total leukocyte antigen CD45 [50].

It is considered that circulating EPCs with the phenotype $\mathrm{CD} 4^{+} \mathrm{CD} 45^{-}$have the greatest ability to differentiate into mature ECs and are most actively mobilized at endothelial damage. Concentration of the $\mathrm{CD} 34^{+} \mathrm{CD} 45^{-}$and $\mathrm{CD} 14^{+} \mathrm{Tie}^{+} \mathrm{KDR}^{+}$ phenotypes of EPCs in the peripheral blood is closely associated with the severity of atherosclerotic lesion and ED at various diseases of the CVS, including DM [51-53].

In the general population, the level of circulating $\mathrm{CD} 4^{+} / \mathrm{CD} 45^{-}$-EPCs positively correlates with obesity, left ventricular hypertrophy and the number of other traditional cardiovascular risk factors, and depends on the amount of cardiovascular risk factors [54]. It is supposed that the level of $\mathrm{CD} 34^{+} \mathrm{CD} 45^{-}$-cells may indirectly reflect the prevalence of atherosclerosis and correlated with the number of potentially endangered atheroma [55].
In 1996, the ISHAGE (International Society for Hematotherapy and Graft Engineering) protocol was developed to identify stem and progenitor cells, which was successfully implemented in multicenter trials [56]. Schmidt-Lucke and el. [36] adapted the ISHAGE protocol by including a fraction of CD45 cells in the analysis, suggesting that it could contain «true» circulating EPCs [57]. The quantification was performed after a consistent gating strategy [56], and the CD34 $4^{+}$-cells were further subdivided into 3 subpopulations: CD 45 , D $45^{\mathrm{dim}}$ and CD45 $5^{\text {bright }}$.

The data obtained in this protocol revealed the diagnostic value of the phenotype $\mathrm{CD} 34^{+} \mathrm{CD} 45^{\mathrm{dim}} \mathrm{KDR}^{+}$. An inverse correlation was found between the number $\mathrm{CD} 34^{+} \mathrm{CD} 45^{\mathrm{dim}} \mathrm{KDR}^{+}$ and ischemic heart disease, as well as the number of cardiovascular risk factors, even after correcting the activity of the disease and the number of affected coronary arteries [36].

It is established that in response to ischemia in patients with acute coronary syndrome and unstable angina the concentration of $\mathrm{CD} 34^{+} \mathrm{CD} 45^{-}$ -EPCs increase [36]. Additionally, the concentration of $\mathrm{CD} 34^{+} \mathrm{CD} 45^{-}$-cells may increase in patients with the obliterating atherosclerosis of arteries of the lower extremities [38, 58].

It is determined that $\mathrm{CD} 34^{+} \mathrm{CD} 45^{-}$-cells of non-hemopoietic origin are phenotypically indistinguishable from BM-EPCs and functionally differ only in ability to form a colony during cultivation [59]. This creates difficulties in identifying the origin of EPCs in the case of verification of CD34 antigen expression in CD45-negative mononuclear cells. More complex antigenic phenotypes may be more specific for EPCs, however, the lower reproducibility limits their use in clinical practice.

Consequently, more complex antigenic combinations, in spite of providing additional information about the cells, do not increase the efficiency of cell determination as clinical biomarkers [60]. Nevertheless, the functional ability of EPCs to stimulate the neoangiogenesis is not an attribute of their origin and is not directly related to their phenotype [61].

\section{Conclusion}

Endothelial progenitor cells are the main pool of cells involved in vascular regeneration and postnatal neovascularization, have the ability to synthesize 
vascular growth factors and various cytokines that stimulate vasculogenesis and angiogenesis. Numerous studies have shown the importance of EPCs as an independent predictor of cardiovascular events in patients with high cardiovascular risk. However, there is no standard method for the identification of EPCs and the generally accepted combination of EPCs surface antigens. At the same time, the phenotypes of EPCs as CD34 ${ }^{+} \mathrm{CD} 45^{-} \mathrm{CD} 34^{+} \mathrm{CD} 45^{-} \mathrm{KDR}^{+}$ possess the highest potential and can be considered as a diagnostic marker of EPCs.

\section{References}

1. Гоженко АИ, Кузнецова АС, Кузнецова ЕС, Быць ТН, Сусла АБ. Эндотелиальная дисфункция в патогенезе осложнений сахарного диабета. Сообщение I. Эндотелиальная дисфункция: этиология, патогенез и методы диагностики. Ендокринологія. 2017;22(2):171-81. (Gozhenko AI, Kuznetsova AS, Kuznetsova YeS, Byts TN, Susla AB. Endothelial dysfunction in the pathogenesis of diabetes complications. The message I. Endothelial dysfunction: etiology, pathogenesis and diagnostic methods». Endocrinology. 2017;22(2):171-81).

2. Гоженко АИ, Кузнецова АС, Кузнецова ЕС, Кузнецова ЕН, Быць ТН, Жуков В. Морфо-функциональные основы эндотелиальной дисфункции при сахарном диабете. Journal of Education, Health and Sport. 2017;7(6): 516-24. (Gozhenko AI, Kuznetsova AS, Kuznetsova YeS, Kuznetsova YuN, Byts TM, Zukow V. Morpho-functional basis of endothelial dysfunction in diabetes mellitus. Journal of Education, Health and Sport. 2017;7(6):516-24).

3. Gozhenko AI, Kuznetsova AS, Kuznetsov YeS, Kuznetsova YeN, Byts TM. The number of circulating endotheliocytes in the blood plasma of the patients with diabetes mellitus increases. Pharmacologyonline. 2017;3:82-90.

4. Tepper OM, Capla JM, Galiano RD. Adult vasculogenesis occurs through the in situ recruitment, proliferation and tubulization of circulating bone marrow-derived cells. Blood. 2005;105:1068-77.

5. Asahara T, Murohara T, Sullivan A, Silver M, van der Zee R. Isolation of putative progenitor endothelial cells for angiogenesis. Science. 1997;275 (5302):964-7.

6. Bayes-Genis A, Galvez-Monton C, Prat-Vidal C, Soler-Botija C. Cardiac adipose tissue: A new frontier for cardiac regeneration. Int J Cardiol. 2012;167(1):22-5.

7. Endtmann C, Ebrahimian T, Czech T, Arfa O, Laufs U, Fritz M. Angiotensin II impairs endothelial progenitor cell number and function in vitro and in vivo: implications for vascular regeneration. Hypertension. 2011;58(3):394-403.

8. Caiado F, Dias S. Endothelial progenitor cells and integrins: adhesive needs. Fibrogenesis tissue repair. 2012;5:4.

9. Urbich C, Dimmeler S. Endothelial progenitor cells: characterization and role in vascular biology. Circulation research. 2004;95(4):343-53.

10. Grunewald M, Avraham I, Dor Y. VEGF-induced adult neovascularization: recruitment, retention, and role of accessory cells. Cell. 2006;124:175-89.

11. Мичурова МС, Калашников ВЮ, Смирнова ОМ, Кононенко ИВ, Иванова ОН. Роль эндотелиальных прогениторных клеток в развитии осложнений сахарного диабета. Сахарный диабет. 2015;1:24-32. (Michurova MS, Kalashnikov VYu, Smirnova OM, Kononenko IV, Ivanova ON. The role of endothelial progenitor cells in the development of complications of diabetes mellitus. Sakharnyy diabet. 2015;1:24-32).

12. Lapidot T, Dar A, Kollet O. How do stem cells find their way home. Blood. 2005;106:1901-10.

13. Ceradini DJ, Kulkarni AR, Callaghan MJ. Progenitor cell trafficking is regulated by hypoxic gradients through HIF-1 induction of SDF-1. Nat Med. 2004;10: 858-64.

14. Zhang Q, Yin H, Liu P, Zhang H, She M. Essential role of HDL on endothelial progenitor cell proliferation with PI3K/Akt/cyclin D1 as the signal pathway. Exp Biol Med. 2010;235:1082-92.

15. Lolmede K, Campana L, Vezzoli M. Inflammatory and alternatively activated human macrophages attract vessel-associated stem cells, relying on separate HMGB1-and MMP-9-dependent pathways. Leukoc Biol. 2009;85:779-87.

16. Ohki Y, Heissig B, Sato Y. Granulocyte colony-stimulating factor promotes neovascularization by releasing vascular endothelial growth factor from neutrophils. FASEB J. 2005;19:2005-7.

17. Levesque JP, Takamatsu Y, Nilsson SK, Haylock DN, Simmons PJ. Vascular cell adhesion molecule-1 (CD106) is cleaved by neutrophil proteases in the bone marrow following hematopoietic progenitor cell mobilization by granulocyte colony-stimulating factor. Blood. 2001;98:1289-97.

18. Heissig B, Hattori K, Dias S. Recruitment of stem and progenitor cells from the bone marrow niche requires MMP-9 mediated release of kit-ligand. Cell. 2002;109:625-37.

19. Zampetaki A, Kirton JP, Xu Q. Vascular repair by endothelial progenitor cells. Cardiovasc Res. 2008;78:413-21.

20. De Boer HC, Verseyden C, Ulfman LH. Fibrin and activated platelets cooperatively guide stem cells to a vascular injury and promote differentiation towards an endothelial cell phenotype. Arterioscler Thromb Vasc Biol. 2006;26:1653-9.

21. Langer H, May AE, Daub K. Adherent platelets recruit and induce differentiation of murine embryonic endothelial progenitor cells to mature endothelial cells in vitro. Circ Res. 2006;98:e2-10.

22. Lev EI, Estrov Z, Aboulfatova K. Potential role of activated platelets in homing of human endothelial progenitor cells to subendothelial matrix. Thromb Haemost. 2006;96:498-504.

23. Kawamoto A, Gwon HC, Iwaguro H, Yamaguchi JI, Uchida S, Masuda H. Therapeutic potential of ex vivo expanded endothelial progenitor cells for myocardial ischemia. Circulation. 2001;103(5):634-7.

24. Kawamoto A, Tkebuchava T, Yamaguchi J, Nishimura H, Yoon YS, Milliken $\mathrm{C}$, et al. Intramyocardial transplantation of autologous endothelial progenitor cells for therapeutic neovascularization of myocardial ischemia. Circulation. 2003;107(3):461-8.

25. Yamaguchi J, Kusano KF, Masuo O, Kawamoto A, Silver M, Murasawa S, et al. Stromal cell-derived factor-1 effects on ex vivo expanded endothelial progenitor cell recruitment for ischemic neovascularization. Circulation. 2003;107(9):1322-8.

26. Chen SC, Song GY, Sun Y, Liu N. The relationship between oxidative stress and endothelial progenitor cells count in the first degree relatives of diabetes mellitus. Zhonghua Nei Ke Za Zhi. 2012;51(3):197-200.

27. Zhang ZG, Zhang L, Jiang Q Chopp M. Bone marrow-derived endothelial progenitor cells participate in cerebral neovascularization after focal cerebral ischemia in the adult mouse. Circ Res. 2002;90(3):284-8.

28. Fan Y, Shen F, Frenzel T, Zhu W, Ye J, Liu J, et al. Endothelial progenitor cell transplantation improves long-term stroke outcome in mice. Ann Neurol. 2010;67(4):488-97.

29. Dimmeler S, Zeiher AM. Vascular repair by circulating endothelial progenitor cells: the missing link in atherosclerosis. J Mol Med. 2004;83(10):671-7.

30. Liu ZJ, Velazquez OC. Hyperoxia, endothelial progenitor cell mobilization, and diabetic wound healing. Antioxid Redox Signal. 2008;10(11):1869-82.

31. Michowitz Y, Goldstein E, Wexler D. Circulating endothelial progenitor cells and clinical outcome in patients with congestive heart failure. Heart. 2007; 93(9):1046-50.

32. Tepper OM, Galiano RD, Capla M. Human endothelial progenitor cells from type II diabetics exhibit impaired proliferation, adhesion, and incorporation into vascular structures. Circulation. 2002;106:2781-6.

33. Семенова АЕ, Сергиенко ИВ, Домбровский АЛ, Рвачева АВ. Роль эндотелиальных прогениторных клеток при атеросклерозе. Атеросклероз и дислипидемии. 2012;3:14-24. (Semenova AYe, Sergienko IV, Dombrovskiy AL, Rvacheva AV. Endothelial progenitor cells and atherosclerotic process. Ateroskleroz i dislipidemii. 2012;3:14-24.

34. Krankel N, Adams V, Linke A. Hyperglycemia reduces survival and impairs function of circulating blood-derived progenitor cells. Arterioscler Thromb Vasc Biol. 2005;25:698-703.

35. Белова ЮА, Чуксина ЮЮ, Шевелев СВ, Яздовский ВВ, Котов СВ Уровень эндотелиальных прогениторных клеток у больных с ишемическим инсультом и эффективность реабилитации. Альманах клинической медицины. 2015;(39):45-50. (Belova YuA, Chuksina YuYu, Shevelev SV, Yazdovskiy VV, Kotov SV. Level of endothelial progenitor cells in patients with ischemic stroke and efficacy of rehabilitation. Al'manah kliniceskoj mediciny. 2015;(39):45-50).

36. Schmidt-Lucke C, Fichtlscherer S, Aicher A, Tschöpe C, Schultheiss HP, Zeiher AM, et al. Quantification of circulating endothelial progenitor cells using the modified ISHAGE protocol. PloS One. 2010;5(11):e13790.

37. Werner N, Kosiol S, Schiegl T, Ahlers P, Walenta K. Circulating endothelial progenitor cells and cardiovascular outcomes. N Engl J Med. 2005; 353:999-1007. 
38. Hill JM, Zalos G, Halcox JP, Schenke WH, Waclawiw MA. Circulating endothelial progenitor cells, vascular function, and cardiovascular risk. N Engl J Med. 2003;348(7):593-600.

39. Khan SS, Solomon MA, McCoy JP. Detection of circulating endothelial cells and endothelial progenitor cells by flow cytometry. Cytometry Part B Clinical Cytometry. 2005;64(1):1-8.

40. Fadini GP, Ozaki T, Taguchi A, Meigs J, Dimmeler S. Circulating progenitor cell count for cardiovascular risk stratification: a pooled analysis. PLoS One. 2010;5(7):e11488.

41. Timmermans F, Van Hauwermeiren F, De Smedt M, Raedt R, Plasschaert F, De Buyzere ML, et al. Endothelial outgrowth cells are not derived from CD133+ cells or CD45+ hematopoietic precursors. Arterioscler Thromb Vasc Biol. 2007;28:1572-9.

42. Lin Y, Weisdorf DJ, Solovey A, Hebbel RP. Origins of circulating endothelial cells and endothelial outgrowth from blood. J Clin Invest. 2000;105:71-7.

43. Bayes-Genis A, Galvez-Monton C, Prat-Vidal C, Soler-Botija C. Cardiac adipose tissue: A new frontier for cardiac regeneration. Int $\mathrm{J}$ Cardiol. 2012;167(1):22-5

44. Liu JW, Dunoyer-Geindre S, Serre-Beinier V, Mai G, Lambert JF, Fish RJ, et al. Characterization of endothelial-like cells derived from human mesenchymal stem cells. J Thromb Haemost. 2007;5(4):826-3.

45. Березин AE, Кремзер АА. Постнатальные эндотелиальные прогениторные клетки как биологические маркеры неоангиогенеза и реэндотелизации. Серце і судини. 2013;2:92-7. (Berezin AYe, Kremzer AA. Postnatal endothelial progenitor cells as biological markers of neoangiogenesis and endothelialization. Sertse i sudyny. 2013;2:92-7).

46. Gehling UM, Ergun S, Schumacher U. In vitro differentiation of endothelial cells from AC133-positive progenitor cells. Blood. 2000;95(10):3106-12.

47. Timmermans F, Van Hauwermeiren F, De Smedt M, Raedt R, Plasschaert F, De Buyzere ML, et al. Endothelial outgrowth cells are not derived from $\mathrm{CD} 133^{+}$cells or $\mathrm{CD} 45^{+}$hematopoietic precursors. Arterioscler Thromb Vasc Biol. 2007;28:1572-79.

48. Masuda H, Alev C, Akimaru H. Methodological development of a clonogenic assay to determine endothelial progenitor cell potential. Circulation research. 2011;109(1):20-37.

49. Case J, Mead LE, Bessler WK. Human CD34+AC133+VEGFR-2+ cells are not endothelial progenitor cells but distinct, primitive hematopoietic progenitors. Exp Hematol. 2007;35(7):1109-18

50. Shi Q, Rafii S, Wu MH. Evidence for circulating bone marrow-derived endothelial cells. Blood. 1998;92(2):362-7.

51. Березин АЕ, Кремзер АА. Взаимосвязь между факторами кардиоваскулярного риска и уровнем циркулирующих эндотелиальных прогениторных клеток у пациентов с ангиографически подтвержденной ишемической болезнью сердца. Український медичний часопис. 2013;3(95):170-5. (Berezin AYe, Kremzer AA. The relationship between cardiovascular risk factors and the level of circulating endothelial progenitor cells in patients with angiographically confirmed coronary heart disease. Ukrayins'kyy medychnyy chasopys. 2013;3(95):170-5).

52. Bozdag-Turan I, Turan RG, Paranskaya L, Arsoy NS, Turan CH, Akin I, et al. Correlation between the functional impairment of bone marrow-derived circulating progenitor cells and the extend of coronary artery disease. J Transl Med. 2012 Jul;10(1):143.

53. Yoder MC. Human endothelial progenitor cells. Cold Spring Harb Perspect Med. 2012;2(7):a006692.

54. Fabbri-Arrigoni FI, Clarke L, Wang G, Charakida M, Ellins E, Halliday N, et al. Levels of circulating endothelial cells and colony-forming units are influenced by age and dyslipidemia. Pediatr Res. 2012 Sep;72(3):299-304.

55. Padfield GJ, Tura-Ceide O, Freyer E, Barclay GR, Turner M, Newby DE, et al. Endothelial progenitor cells, atheroma burden and clinical outcome in patients with coronary artery disease. Heart. 2013;99(11):791-8.

56. Sutherland D, Anderson L, Keeney M, Nayar R, Chin-Yee I. The ISHAGE guidelines for CD34+ cell determination by flow cytometry. International Society of Hematotherapy and Graft Engineering. J Hematother. 1996 Jun;5(3):213-26.

57. Ingram DA, Caplice NM, Yoder MC. Unresolved questions, changing definitions, and novel paradigms for defining endothelial progenitor cells. Blood. 2005 Sep;106(5):1525-31.

58. Morishita T, Uzui H, Nakano A, Mitsuke Y, Geshi T, Ueda T, et al. Number of endothelial progenitor cells in peripheral artery disease as a marker of severity and association with pentraxin-3, malondialdehyde-modified low-density lipoprotein and membrane type-1 matrix metalloproteinase. J Atheroscler Thromb. 2012;19(2):149-58.
59. Tamura M, Sebastian S, Gurates B, Yang S, Fang Z, Bulun SE. Vascular endothelial growth factor up-regulates cyclooxygenase-2 expression in human endothelial cells. J Clin Endocrinol Metab. 2002 Jul;87(7):3504-7.

60. Fadini GP, Losordo D, Dimmeler S. Critical re-evaluation of endothelial progenitor cell phenotypes for therapeutic and diagnostic use. Circ Res. 2012 Feb;110(4):624-37.

61. Huang CY, Shih CM, Tsao NW, Lin YW, Huang PH, Wu SC, et al. Dipeptidyl peptidase-4 inhibitor improves neovascularization by increasing circulating endothelial progenitor cells. Br J Pharmacol. 2012;167(7):1506-19.

(Надійшла до редакції 09.11.2018р.)

\section{Механизмы регенерации эндотелия при сахарном диабете}

\section{А.С. Кузнецова, Е.С Кузнецова, Т.Н. Быць, Л.М. Бобрик, Е.Н. Кузнецова, А.И. Гоженко}

ГП «Украинский научно-исследовательский институт медицины транспорта МЗ Украины», г. Одесса

Резюме. Эндотелий сосудов - основной орган-мишень, страдающий при сахарном диабете (СД) и сердечно-сосудистых заболеваниях (ССЗ). В обзоре рассмотрена роль эндотелиальных прогениторных клеток (ЭПК) в регенерации эндотелия и в образовании новых кровеносных сосудов. Описаны механизмы миграции и мобилизации ЭПК из костного мозга в зону повреждения. Приведены данные о снижении количества и нарушении функции ЭПК при ССЗ и СД. В статье представлены данные о гетерогенности популяции ЭПК, о различных комбинациях поверхностных маркеров, которые используются для идентификации данных клеток. Вместе с тем на данный момент не разработаны протоколы для идентификации ЭПК, что подтверждает актуальность поиска фенотипа ЭПК, который был бы принят за стандарт.

Ключевые слова: эндотелиальные прогениторные клетки, ангиогенез, регенерация эндотелия, эндотелиальная дисфункция, сахарный диабет.

\section{Механізми регенерації ендотелію за цүкрового діабету}

\section{Г.С. Кузнецова, К.С. Кузнецова, Т.М. Биць, Л.М. Бобрик, О.М. Кузнецова, А.І. Гоженко}

ДП «Український науково-дослідний інститут медицини транспорту МО3 України», м. Одеса

Резюме. Ендотелій судин — основний орган-мішень, що потерпає за цукрового діабету (ЦД) і серцево-судинних захворювань (ССЗ). В огляді розглянуто роль ендотеліальних прогеніторних клітин (ЕПК) у регенерації ендотелію та утворенні нових кровоносних судин. Описано механізми міграції та мобілізації ЕПК із кісткового мозку в зону пошкодження. Наведено дані про зниження кількості та порушення функції ЕПК за ССЗ і ЦД, а також про гетерогенність популяції ЕПК, про різні комбінації поверхневих маркерів, які використовуються для ідентифікації даних клітин. Наразі не існує протоколу для ідентифікації ЕПК, що підтверджує актуальність пошуку фенотипу ЕПК, який може буде прийнятий за стандарт.

Ключові слова: ендотеліальні прогеніторні клітини, ангіогенез, регенерація ендотелію, ендотеліальна дисфункція, цукровий діабет. 